\title{
I Konferencja Naukowa Nowotworów
}

W dniach 5 i 6 kwietnia br. odbyła się w Warszawie I Konferencja Naukowa czasopisma Nowotwory Journal of Oncology. Jej inicjatorem i szefem Komitetu Naukowego był Przewodniczący Polskiego Towarzystwa Onkologicznego prof. Jacek Jassem. Konferencję zorganizowano w 90-lecie naszego pisma: pierwszy zeszyt Biuletynu Polskiego Komitetu do Zwalczania Raka ukazał się w kwietniu 1923 roku.

Prof. Jassem nadał Konferencji, nowatorską w warunkach polskich, formułę debat oksfordzkich, stąd jej nazwa „Debaty Onkologiczne". Wybitni specjaliści starli się w bezpośrednich dyskusjach, poważnych w treści a nieco żartobliwych w formie. Wzorem turniejów bokserskich, dyskutanci wkraczali na salę wświetle jupiterów, przy dźwiękach fanfar, z gestem zapowia- danego zwycięstwa, a moderatorzy występowali w białych koszulach z czarnymi muszkami, jak arbitrzy w ringu. A wszystko przy czynnym udziale słuchaczy, którzy przed i po debacie wyrażali swój werdykt w głosowaniach elektronicznych.

Doskonały dobór tematów "pojedynków”, świetne prezentacje (wszyscy dyskutanci potraktowali swoje role niezwykle sumiennie i przygotowali błyskotliwe wystąpienia) i wspaniała atmosfera na sali zadecydowały o autentycznym sukcesie „Debat”. Podczas sesji audytorium było przepełnione, a kuluary świeciły pustkami (wiemy, że bywa nieraz odwrotnie).

Na zakończenie pierwszego dnia przedstawiono film „Chemia"Pawła Łozińskiego, po którym zorganizowano spo-
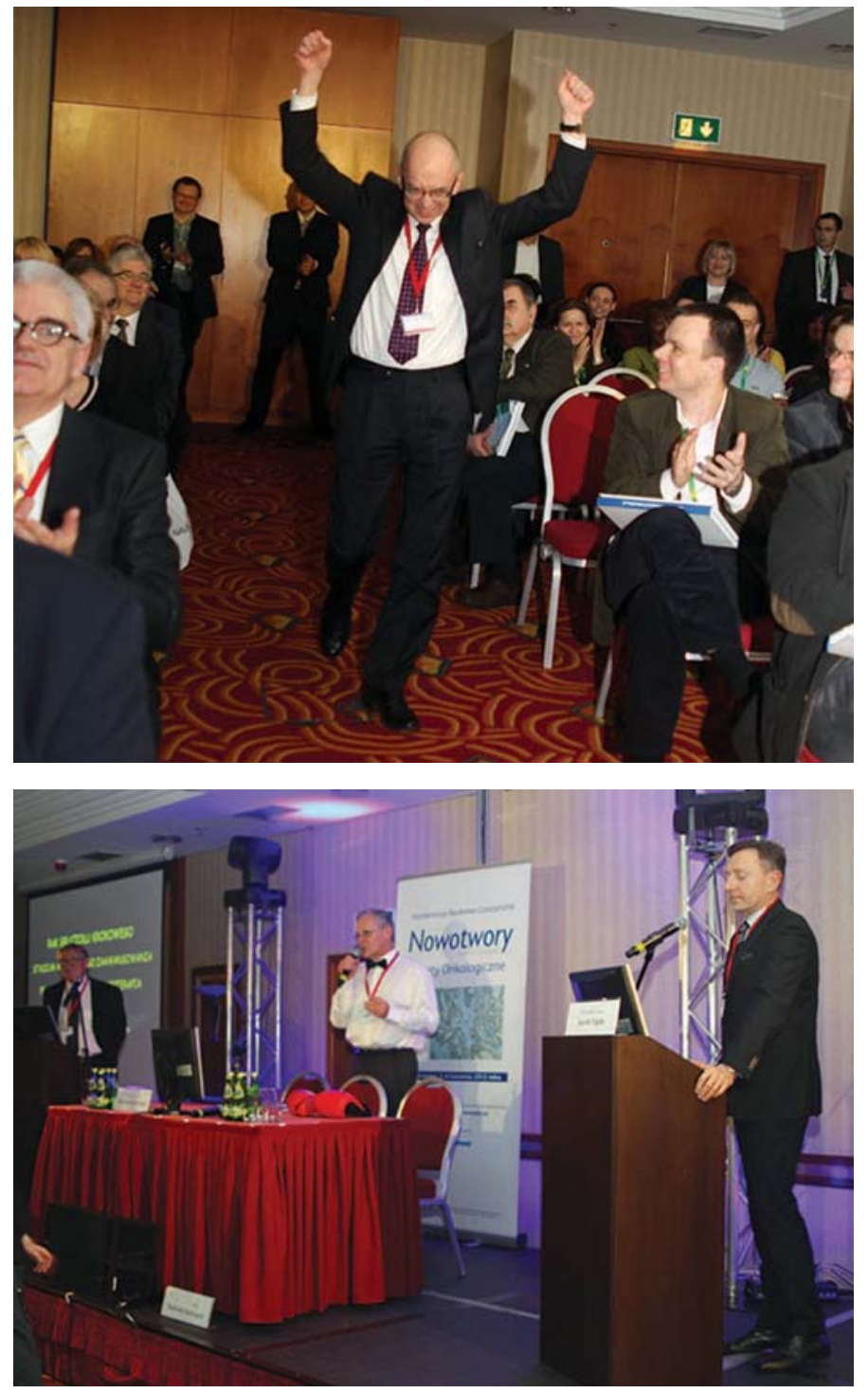

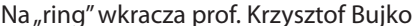

"Walka”: prof. Andrzej Borkowski kontra prof. Jacek Fijuth, moderuje prof. Maciej Krzakowski 


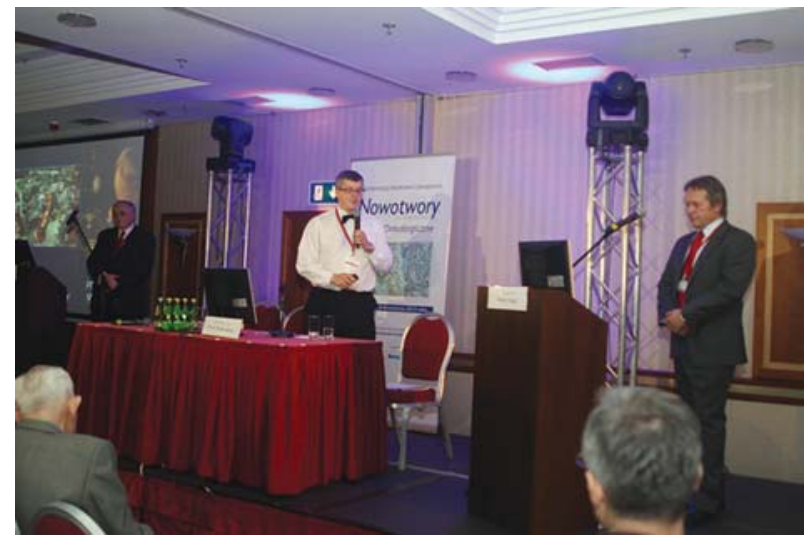

tkanie i dyskusję z reżyserem. Film wywołał autentyczne poruszenie wśród widzów, okazał się świetnym kontrapunktem dla wcześniejszych obrad. Potem zaproszono na koncert.

W przeddzień „Debat” odbyło się robocze spotkanie poświęcone wypracowaniu strategii dla polskiej onkologii. Szeroka reprezentacja onkologów z całego kraju dyskutowała w kilku zespołach problemowych. Na koniec przewodniczący zespołów przedstawili wnioski na spotkaniu plenarnym.

Bezbłędną organizację I Konferencji Nowotworów zapewnił wydawca - Via Medica. Ukazał sie też specjalny
Starcie prof. Wojciecha Witkiewicza i prof. Adama Dzikiego — ${ }_{\text {„sędzią }}$ w ringu" jest prof. Piotr Rutkowski

„konferencyjny" zeszyt pisma. Wszyscy autorzy prezentacji w „Debatach" zapewnili, że przekażą swoje wystąpienia in extenso do druku w regularnych edycjach Nowotworów.

Jednoznaczny sukces I Konferencji Naukowej naszego pisma przesądził o decyzji przekształcenia jej w imprezę cykliczną. Il Konferencja odbędzie się 11 i 12 kwietnia 2014 r.; uczestnicy obecnej, w osobnym tajnym elektronicznym głosowaniu, zdecydowali, że jej miejscem będzie ponownie Warszawa.

Prof. Edward Towpik

\section{Zjazd Polskiego Towarzystwa Chirurgii Onkologicznej}

W dniach 23-25 maja b.r. w Gdańsku w Polskiej Filharmonii Bałtyckiej im. F. Chopina odbył się XIX Zjazd Polskiego Towarzystwa Chirurgii Onkologicznej, zorganizowany przez dr hab. Tomasza Jastrzębskiego i współpracowników. Przewodniczącym Komitetu Naukowego był Prezes PTChO, prof. Wojciech Zegarski.

Zjazd tradycyjnie poprzedzała XXX Konferencja Naukowo-Szkoleniowa PTChO, tym razem poświęcona zagadnieniom diagnostyki obrazowej u chorych na nowotwory przewodu pokarmowego. Ponadto — również zgodnie z tradycją — przed rozpoczęciem Zjazdu odbył się kurs wprowadzający do specjalizacji z chirurgii onkologicznej, w którym uczestniczyło niemal 60 chirurgów ogólnych. Zjazdowi towarzyszyły

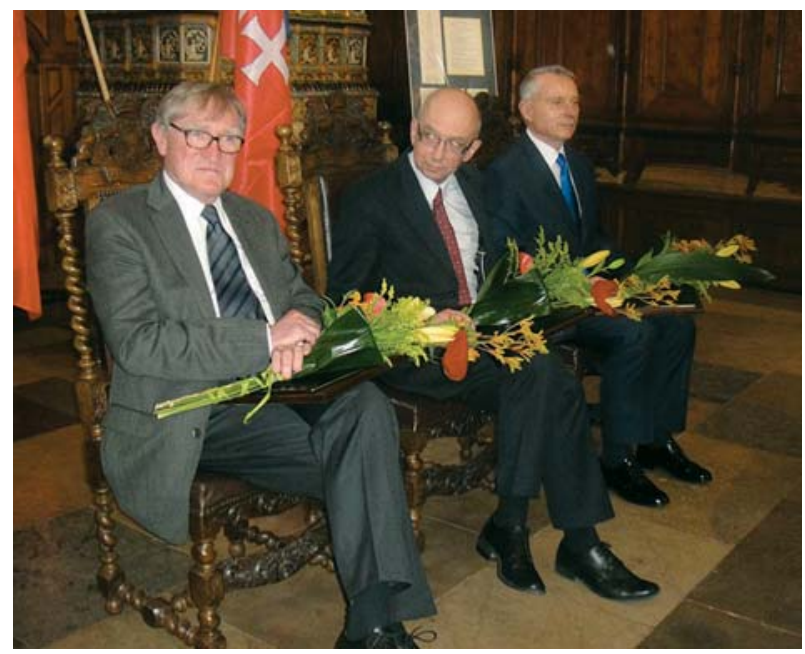

też sesje pielęgniarskie, spotkania sekcji PTChO i grup roboczych (np. Rejestr GIST) oraz inne wydarzenia.

Otwarcie Zjazdu miało miejsce w miejscu niezwykłym — w gdańskim Dworze Artusa. W uroczystości uczestniczyli i zostali obdarzeni stosownymi dyplomami nowi Członkowie Honorowi Towarzystwa: prof. Andrzej Borkowski, prof. Krzysztof Bujko oraz dr Zbigniew Pawłowicz. Nestor polskiej chirurgii onkologicznej prof. Andrzej Kułakowski wręczył medal „Zasłużony dla PTChO" Prezesowi naszego Towarzystwa w ubiegłej kadencji - prof. Wojciechowi Polkowskiemu.

Honor wygłoszenia Wykładu im. prof. T. Koszarowskiego przypadł prof. Krzysztofowi Hermanowi, który zabrał słucha-
Członkowie Honorowi Polskiego Towarzystwa Onkologicznego: prof. Andrzej Borkowski, prof. Krzysztof Bujko, dr Zbigniew Pawłowicz 

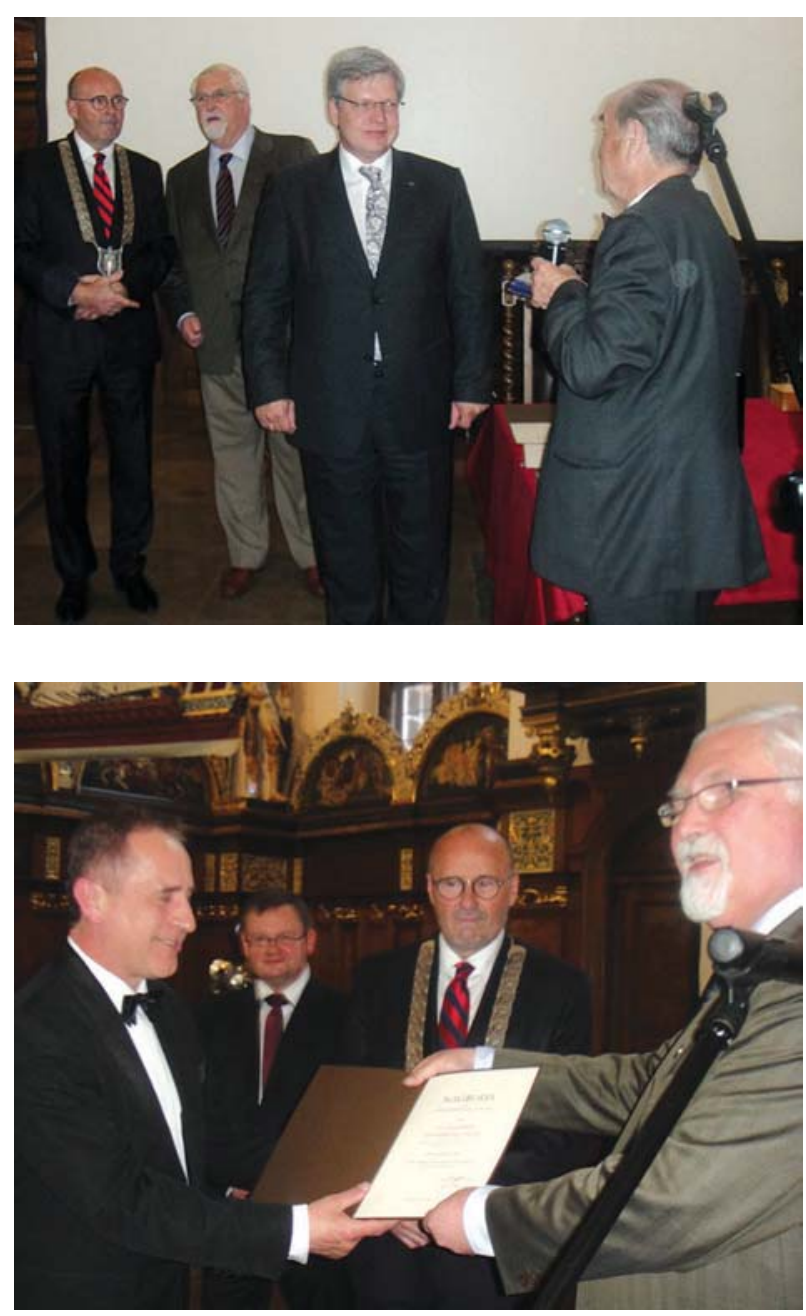

czy w niezwykle starannie i widowiskowo przygotowaną wyprawę w przyszłość chirurgii onkologicznej.

Program Zjazdu obejmował sesje tematyczne poświęcone wielu zagadnieniom chirurgii onkologicznej, a wykłady przedstawili znakomici eksperci w odnośnych dziedzinach. W programie znalazło się też miejsce na szereg doniesień oryginalnych wybranych przez Komitet Naukowy do prezentacji ustnej - wszystkie reprezentowały dobry poziom naukowy. Kolejnych kilkadziesiąt prac przedstawiono w stojących na wysokim poziomie, sesjach plakatowych. Poza ściśle medycznymi tematami uwzględniono także sesję historyczną poświęconą chirurgii w Instytucie Onkologii wWarszawie, $w 60$ rocznicę utworzenia tam przez Tadeusza Koszarowskiego pierwszego w Polsce Oddziału Chirurgii Onkologicznej oraz sesję dotyczącą problemów prawnych i ekonomicznych związanych z praktykowaniem chirurgii onkologicznej.

Wśród gości Zjazdu była grupa przedstawicieli European Society of Surgical Oncology, w tym obecny Prezes ESSO - prof. Graem J. Poston z Liverpoolu. Polskie Towarzystwo Chirurgii Onkologicznej jest narodowym towarzystwem afiliowanym przy ESSO, a członkowie PTChO regularnie opłacający składki członkowskie mogą — bez żadnych
Prof. Andrzej Kułakowski wręcza prof. Wojciechowi Polkowskiemu medal „Zasłużony dla PTChO”

Dr Sławomir Cieśla otrzymuje nagrodę Nowotworów za najlepsze doniesienie ustne podczas XVIII Zjazdu Polskiego Towarzystwa Chirurgii Onkologicznej w Warszawie, 24-26 maja 2012 r. W ceremonii uczestniczy prof. Wojciech Zegarski - Prezes PTChO i prof. Tomasz Jastrzębski — organizator XIX Zjazdu

dodatkowych opłat, jedynie po wypełnieniu deklaracji dostępnej w sekretariacie PTChO (www.ptcho.org.pl) — zostać jednocześnie pełnoprawnymi członkami ESSO.

W czasie Zjazdu odbyło się Walne Zgromadzenie Członków PTChO, w czasie którego między innymi dokonano wyboru Członków Honorowych, których PTChO w należytej, uroczystej oprawie podejmie podczas kolejnego zjazdu. Dr hab. Dawid Murawa otrzymał nagrodę PTChO za wyróżniające osiągnięcia naukowe. Powitano też nowych członków Towarzystwa.

W przyszłym roku w maju w Bydgoszczy odbędzie się jubileuszowy, dwudziesty Zjazd Polskiego Towarzystwa Chirurgii Onkologicznej. Wszystkie informacje będzie można odszukać zarówno w Nowotworach, jak i na stronach internetowych Polskiego Towarzystwa Chirurgii Onkologicznej (www.ptcho.org.pl).

\section{Dr med. Wojciech Wysocki}

Centrum Onkologii — Instytut im. Marii Skłodowskiej-Curie Oddział w Krakowie

Sprawozdanie - za zgoda Redakcji - zmieszczono także na stronie internetowej Polskiego Towarzystwa Chirurgii Onkologicznej-www.ptcho.org.pl. 